\title{
Abundances and breeding phenology of three sympatric grebes (little grebe Tachybaptus ruficollis, great crested grebe Podiceps cristatus and black-necked grebe Podiceps nigricollis) in Dayet El Ferd, Algeria
}

\begin{abstract}
Abundancia y fenología reproductora de tres macaes simpátricos (zampullín chico, Tachybaptus ruficollis; zampullín de cresta grande, Podiceps cristatus; y zampullín de cuello negro, Podiceps nigricollis) en Dayet El Ferd, Argelia
\end{abstract}

Khadidja Moulay Meliani ${ }^{1}$, Ikram Bendahmane1, Mouslim Bara2*, Sadek Atoussi ${ }^{2}$, Moussa Houhamdi2, Noureddine Mostefai ${ }^{1}$

1 Laboratory of Water Conservation Management Soil and Forest, Faculty of Nature and Life Sciences, 13000, University of Tlemcen, Algeria.

2 Laboratoire Biologie, Eau et Environnement (LBEE), Faculté SNV-STU, Université 8 Mai 1945 Guelma. BP. 40124000 Guelma, Algeria.

* Corresponding author: mouslim.bara@gmail.com

\begin{abstract}
In this current study, we examine the abundances and breeding phenology of three sympatric grebes (little, great crested and black-necked grebes) in Dayet El Ferd. These grebes were observed during all the period (2011-2018) in this wetland, except in September when the great crested grebe leaves the region. The abundances of these three grebes show a significant difference. In 2017, the total number of 71 nests was measured. The mean clutch size was $5.23 \pm 1.49$ eggs per nest. The highest number of eggs per nest was ten eggs, and most nests contained three eggs $(\mathrm{N}=18)$.
\end{abstract}

Keywords - Grebes, Dayet El Ferd, breeding, phenology, clutch size.

Ref. bibliográfica: Moulay Meliani, K.; Bendahmane, I.; Bara, M.; Atoussi, S.; Houhamdi, M.; Mostefai, N. 2020. "Abundances and breeding phenology of three sympatric grebes (little grebe Tachybaptus ruficollis, great crested grebe Podiceps cristatus and black-necked grebe Podiceps nigricollis) in Dayet El Ferd, Algeria". Acta zoológica lilloana 64 (2): 73-83. Fundación Miguel Lillo, Tucumán, Argentina. D.O.I.: https://doi. org/10.30550/j.azl/2020.64.2/1

> Recibido: 10 de junio 2020 - Aceptado: 12 de septiembre 2020.

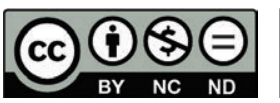




\section{RESUMEN}

En el presente estudio, examinamos las abundancias y la fenología reproductiva de tres macaes simpátricos (zampullines chico, de cresta grande y de cuello negro) en Dayet El Ferd. Estos macaes se observaron durante todo el período (2011-2018) en este humedal, excepto en septiembre, cuando el macá crestado deja la región. Las abundancias de estos tres macaes muestran una diferencia significativa. En 2017, se midió el número total de 71 nidos. El tamaño medio de la nidada fue de $5.23 \pm$ 1.49 huevos por nido, ell mayor número de huevos por nido fue de 10 huevos y la mayoría de los nidos contenía 3 huevos $(\mathrm{N}=18)$.

Palabras clave - Macaes, Dayet El Ferd, cría, fenología, tamaño de la nidada.

\section{INTRODUCTION}

The conservation and management plans rest on the knowledge of wetlands and their selection by waterbirds (Summers, Mavor, Hogg, Harriman, 2011). However, to understand requirements of some species we need heterogenic approaches. Gilchrist, Mallory, Merkel (2015) said that management of birds requires extensive information on their natural history and demography. For example, podicipedidae family has a particular breeding biology, they can building a floating nests to avoid solid ground (Fjeldså, 2004). In Algeria, The information about this family breeding and life history is poorly documented, and the main data reported was on abundance, phenology and behavior of this group (Rouibi, Zitouni, Tahar, Houhamdi, 2013; Senoussi, Nouidjem, Boulekhssaim, 2014; Abdellioui, Bensouilah, Houhamdi, 2015; Athamnia et al., 2015).

The phonological status of the little grebe Tachybaptus ruficollis and the great crested grebe Podiceps cristatus are sedentary-breeding birds in the main Algerian wetlands (Abdellioui, Bensouilah, Houhamdi, 2015). But, the black-necked grebe Podiceps nigricollis is rare in Eastern and Central wetlands of Algeria, but most common in the western region (Bendahmane, Mostefai, Moulai-Melliani, Houhamdi, 2014). This ascertainment is probably due to the neighbouring Moroccan wetlands from Dayet El Ferd (Moroccan population) (Cherkaoui, Bouajaja, Elbanak, Lahrouz, Hanane, 2013). The little grebe occupies a wide spectrum of habitats across its range (Athamnia et al., 2015). The great crested grebe has a widespread distribution occupying most of Europe, Central and South Asia, and North Africa (Abdellioui, Bensouilah, Houhamdi, 2015). The black-necked grebe has a broad distribution from Western Palearctic to North America (Cherkaoui, Bouajaja, Elbanak, Lahrouz, Hanane, 2013).

In this current study, we propose the survey of three sympatric grebes in Dayet El Ferd. First, assessing the abundance of these grebes, second, evaluating regular variation of species number and third, studying their breeding phenology and characteristics. 


\section{MATERIAL AND METHODS}

\section{Study area}

The Dayet El Ferd (Sebdou District, south of Tlemcen, northwest of Algeria) is a continental natural wetland in an endorheic depression. This Dayet $\left(34^{\circ} 28^{\prime} \mathrm{N}\right.$ and $01^{\circ} 15^{\prime} \mathrm{W}$, Figure 1) is an internationally important wetland classified as a Ramsar site since 2004, which extends over 1275 ha and is flooded by brackish water (formed by $\left.\mathrm{MgCl}_{2}\right)($ Bendahmane, 2015). The flora is adapted to this saline substrate. We noted mainly the Crucifers (Diplotaxis erucoides, Moricandia arvensis, Matthiola sp.) and the Chenopodiaceae (Atriplex halimus, Salsola fruticosa, Salicornia fruticosa). The Dayet is surrounded by Tamarix gallica. The climate is semi-arid characterized by two seasons: a short cold winter and a long hot and dry summer. The annual rainfall varies between 300 and $400 \mathrm{~mm}$, and annual temperatures range between $6{ }^{\circ} \mathrm{C}$ and $32{ }^{\circ} \mathrm{C}$ (Benabadji and Bouazza, 2000).

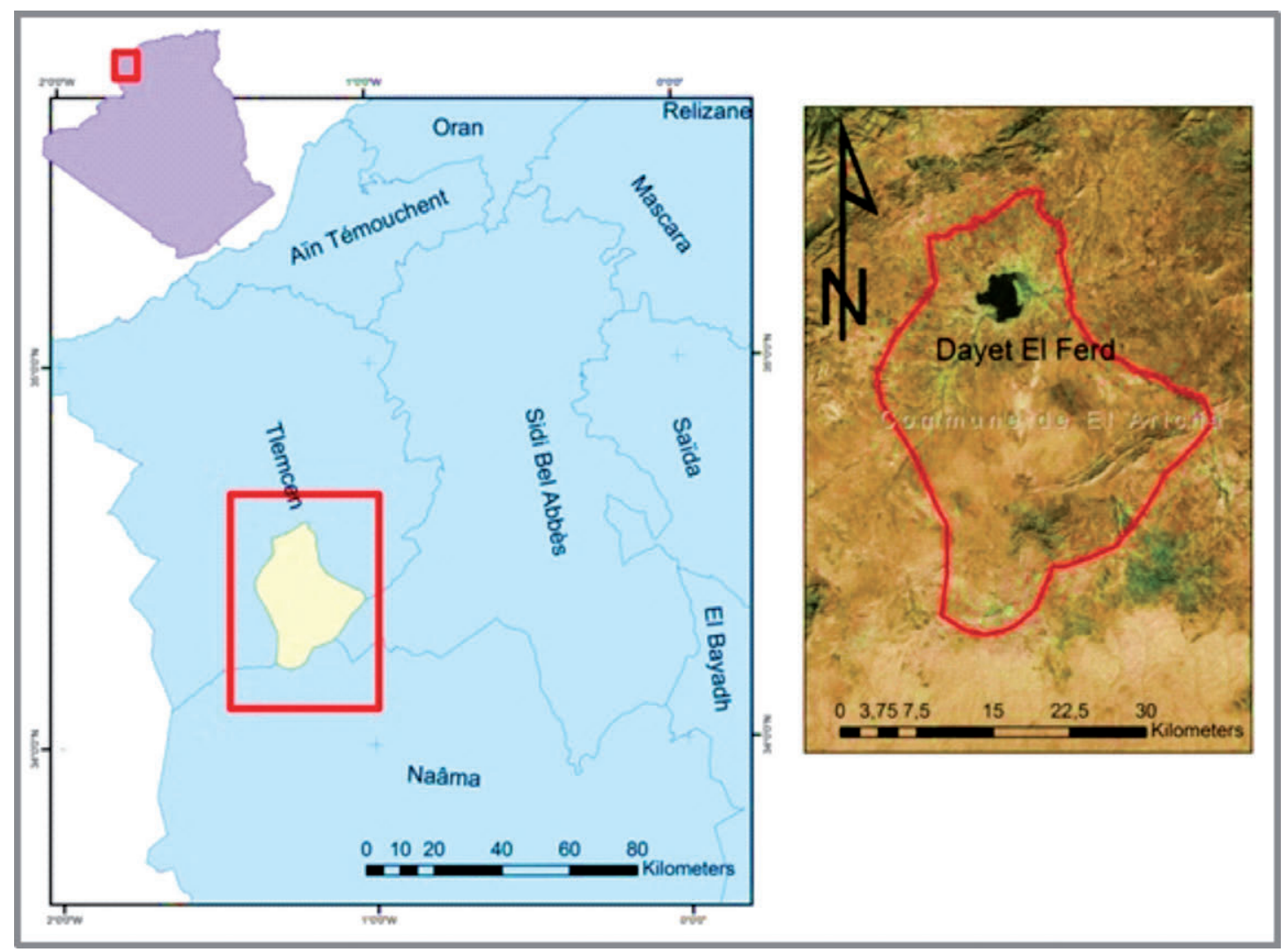

Figure 1. Geographical situation of the study area (Dayet El Ferd, Tlemcen).

Figura 1. Ubicación geográfica del área de estudio (Dayed El Ferd, Tlemcen). 


\section{Sampling method}

The monthly number of individuals (little, great crested and black-necked grebe) in this Dayet was recorded during all years 2011-2018 using a telescope (Kowa 20x60). We applied a PIA method (punctual index abundance) in a fixed observation point situated at the border of the Dayet (Blondel, 1975). Counts were done during the twilight period and took around 10 minutes (Lumpkin and Pearson, 2013). We have also noted the species number of grebes per months from 2011 to 2018.

The breeding study was carried out in 2017. A weekly monitoring of nesting populations of grebes was done between March and August of each year. One visit per week from mid-March until the laying of the 1st egg, then the surveys were conducted 2-3 times per week. The location of the nests was previously detected using a telescope (Kowa 20x60). Biometric parameters of breeding were collected: clutch size, the external and internal diameter of nests, water depth (Bara, Khelifa, Merzoug, Bouslama, Houhamdi, 2014).

\section{Statistical analysis}

Kruskal-Wallis test was applied to compare variation in grebe abundances and species number. Levene's test (Mean) was applied to compare the biometric characteristics of nests. Normality of data distribution was calculated. Breeding parameters of the three species were reported as mean $\pm \mathrm{SD}$. Significant level of all test was á $=5 \%$. We performed analysis using XLSTAT 2014 .

\section{RESULTS}

\section{Abundances of grebes in Dayet El Ferd}

Figure 2 shows the abundance variation of the three grebes in Dayet El Ferd (from 2011 to 218). This figure displayed that in September the great crested grebe leaves the wetland. Also, there was a significant difference between the number of these three grebes (2011-2018) in Dayet El Ferd $(\mathrm{K}=12.11$, p-value $=0.002)$. We noted that this number of individuals of black-necked grebe was highly significant than both little grebe $(p-v a l u e=0.038)$ and great crested grebe $(p$-value $=0.005)$. However, the number of these three podicipedidae did not change between years (2011-2018) $(\mathrm{K}=3.71$, $\mathrm{p}$-value $=0.812)$.

\section{Variation of species number}

The number of Podicipididea species in Dayet El Ferd fluctuated between one to three species. We can observed three species of Podicipididea: the little, great crested and black-necked grebes. We noted that there was a significant differences between 
annual variation in number of species in this wetland $(K=33.7$, p-valueÂ 0.0001$)$. The low number of grebe species in the Dayet was noted in 2018 (Figure 3) with a significant differences between 2018 and 2011 (p-value $=0.005), 2018$ and 2013 $(\mathrm{p}$-value $=0.004), 2018$ and $2016(\mathrm{p}$-value $=0.01)$.

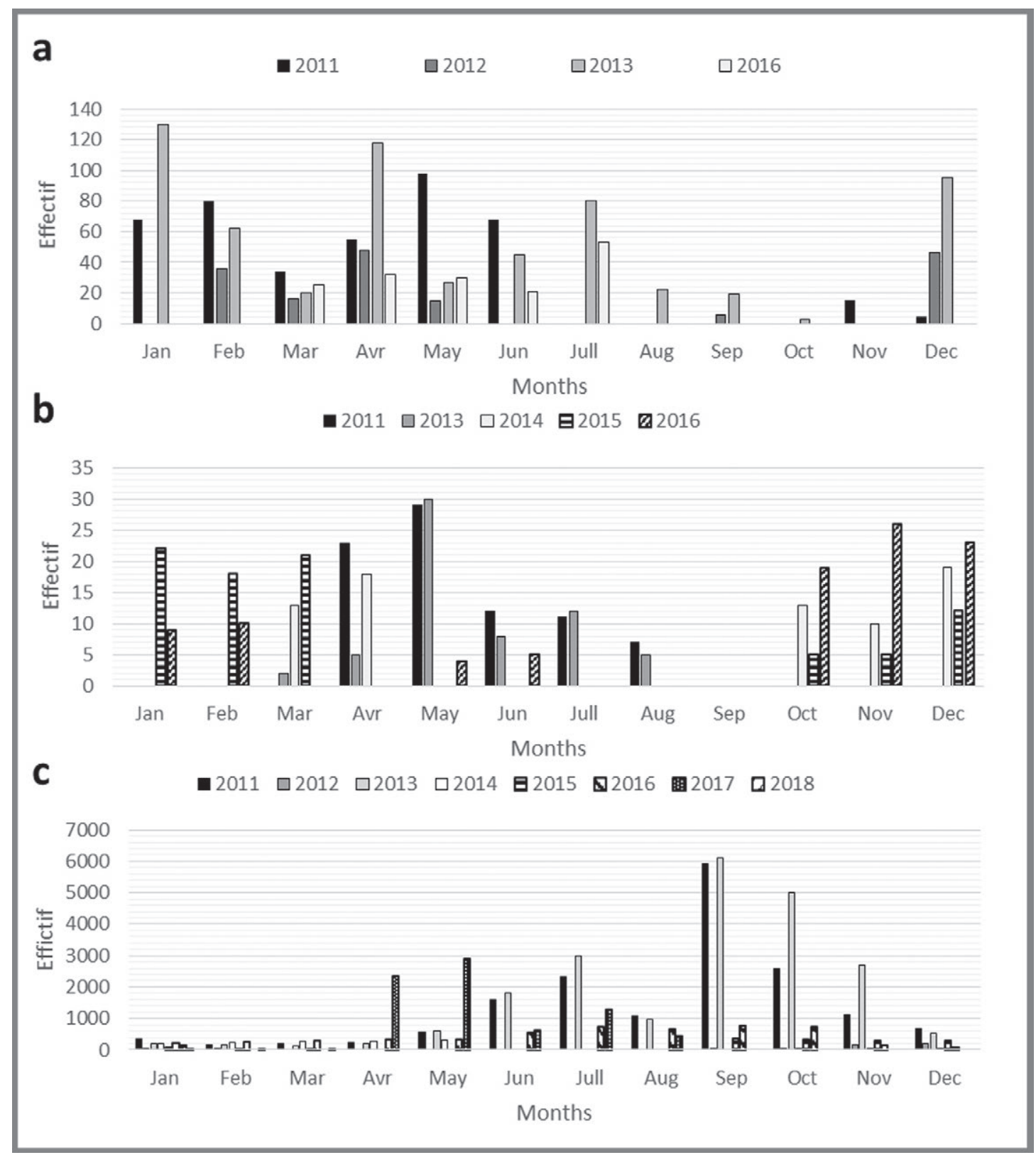

Figure 2. Monthly abundance of the grebes in Dayet El Ferd, a: little grebe, b: great crested grebe, c: black-necked grebe.

Figura 2. Abundancia mensual de los macaes en Dayet El Ferd, a: zampullín grande, b: zampullín de cresta grande, c: zampullín de cuello negro. 


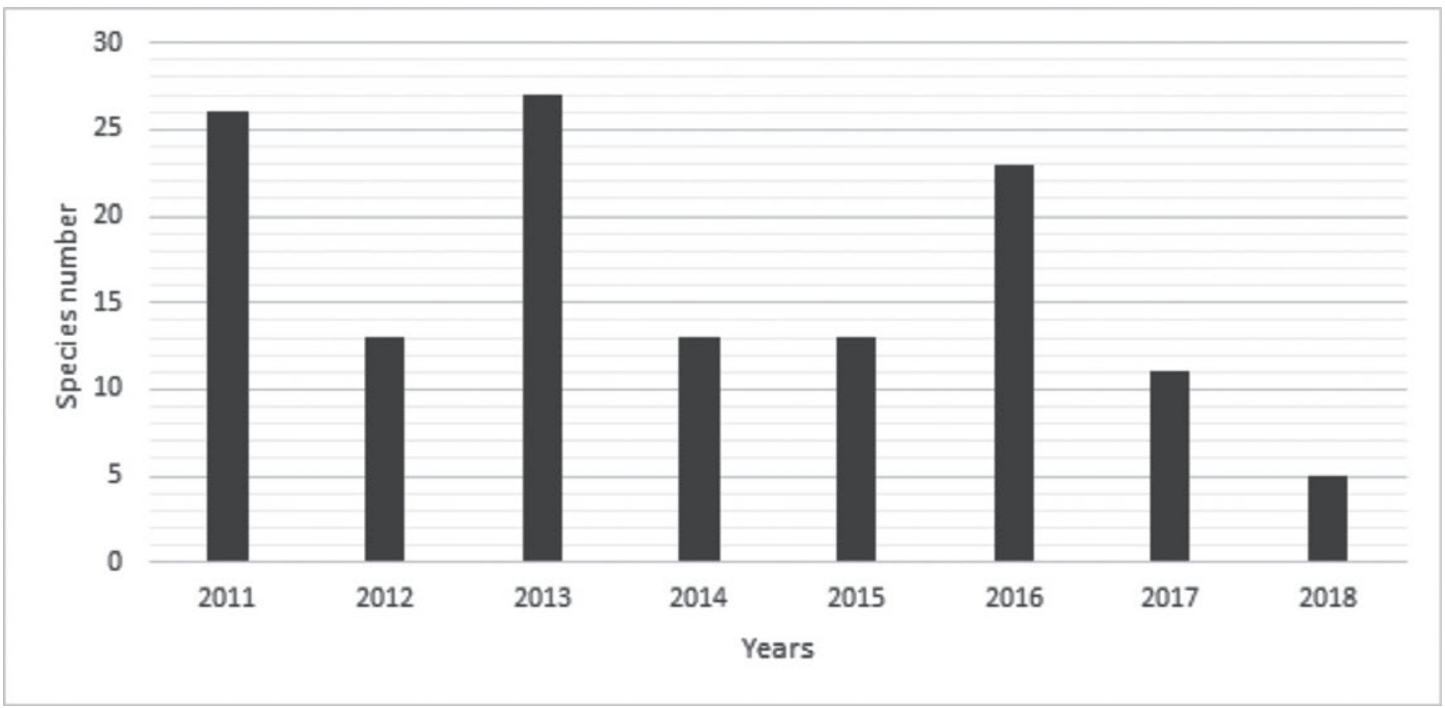

Figure 3. Annual variation of the grebes' species number in Dayet El Ferd (2011-2018).

Figura 3. Variación anual del número de especies de macaes en Dayet El Ferd (2011-2018).

\section{Grebes breeding phenology and characteristics}

A total of 75 nests were surveyed in Dayet El Ferd in 2017 (41 nests of black-necked grebe, 12 nests of great crested grebe, and 22 nests of little grebe). The breeding phenology of the three species of grebes started in mid-march. The biometric characteristics of nests were summarized in table 1 . There were significant differences between the internal diameter of the three grebes nests $(F=13.95$, $p$-value $<0.0001)$, their external diameter $(\mathrm{F}=3.82$, $\mathrm{p}$-value $=0.027)$, and their water depth $(\mathrm{F}=76.59$, p-value $<0.0001)$.

Table 1. Nest biometric characteristics of the three grebes in Dayet El Ferd.

Tabla 1. Características biométricas del nido de los tres macaes en Dayet El Ferd.

\begin{tabular}{|c|c|c|c|c|c|c|c|c|c|}
\hline & \multicolumn{3}{|c|}{ Little grebe } & \multicolumn{3}{|c|}{ Great crested grebe } & \multicolumn{3}{|c|}{ Black-necked grebe } \\
\hline & Max & Mean $\pm S D$ & Min & Max & Mean $\pm S D$ & Min & Max & Mean $\pm S D$ & Min \\
\hline $\begin{array}{l}\text { Internal diameter } \\
\text { (cm) }\end{array}$ & 25,4 & $21 \pm 3,27$ & 13,6 & 26,6 & $24,42 \pm 1,39$ & 22,2 & 25,3 & $\begin{array}{c}18,55 \pm \\
3,89\end{array}$ & 14,1 \\
\hline $\begin{array}{l}\text { External diameter } \\
(\mathrm{cm})\end{array}$ & 29,3 & $\begin{array}{l}26,42 \\
\pm 2,83\end{array}$ & 19,8 & 34,1 & $30,47 \pm 1,65$ & 28,4 & 30 & $\begin{array}{c}27,11 \pm \\
1,36\end{array}$ & 25 \\
\hline Water depth $(\mathrm{cm})$ & 136 & $\begin{array}{c}108,36 \pm \\
21\end{array}$ & 60 & 133 & $\begin{array}{c}122,16 \pm \\
9,41\end{array}$ & 102 & 130 & $\begin{array}{c}66,87 \pm \\
42,9\end{array}$ & 15 \\
\hline
\end{tabular}


In Dayet El Ferd, the little grebe lays between 4 and 10 eggs per nest. The great crested grebe lays between 3 and 5 eggs, while, the black-necked grebe lays between 2 and 8 eggs (Figure 4). The mean clutch size of the three grebes in Dayet El Ferd was $7.63 \pm 1.87$ for the little grebe, $4.16 \pm 0.68$ for the great crested grebe and 3.9 \pm 1.94 for the black-necked grebe.

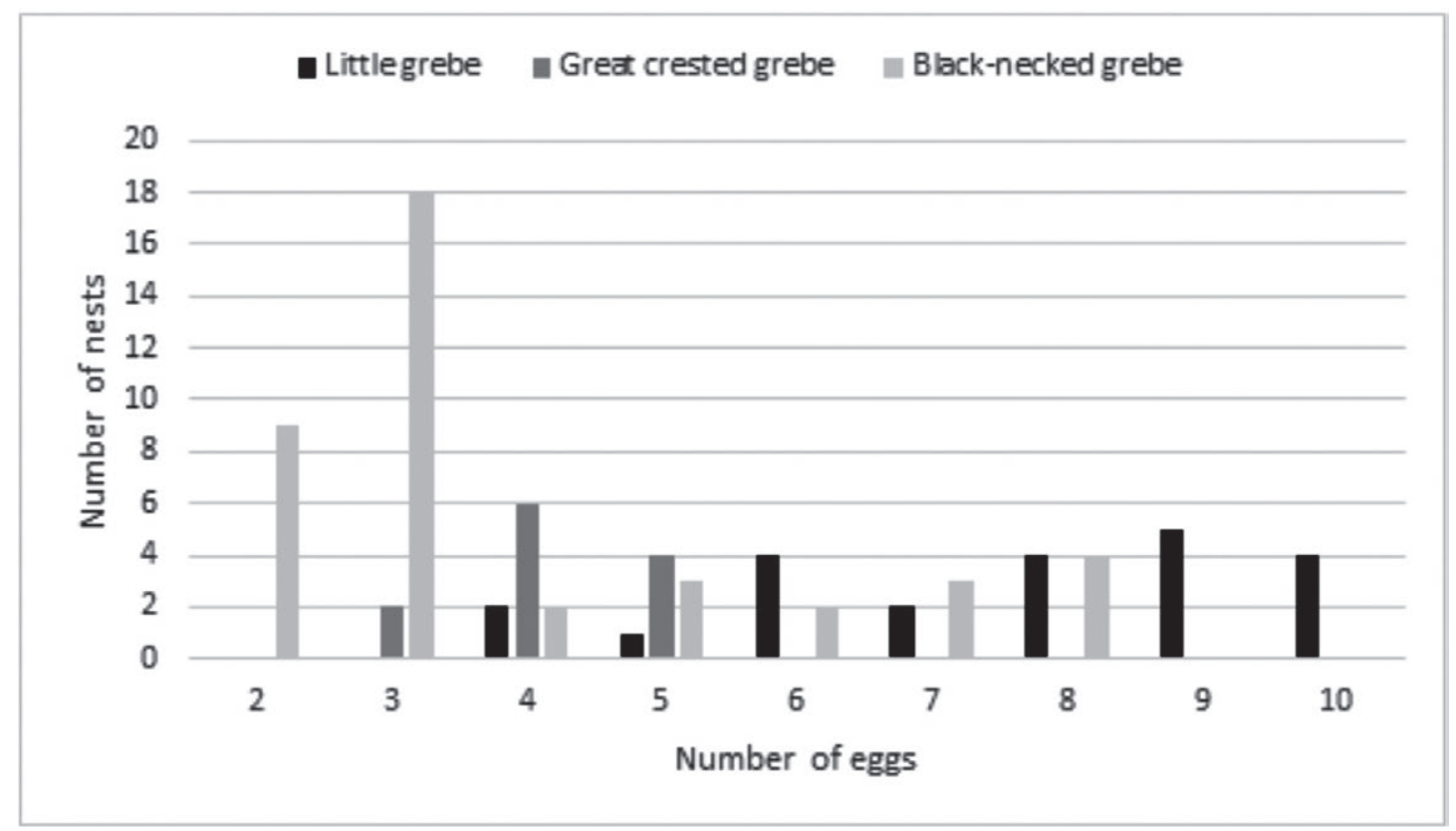

Figure 4. Clutch size of the three grebes in Dayet El Ferd.

Figura 4. Tamaño de la nidada de los tres macaes en Dayet El Ferd.

\section{DISCUSSION}

This current study reported the abundance, distribution and breeding phenology of three sympatric Podicipedidae (the little, the great crested and the black-necked grebe) in Dayet El Ferd (Tlemcen, northwest Algeria). Our results were summarized in three main points: i) this wetland is annually frequented by these three grebes, with a significant difference in the number of individuals, ii) the breeding season of the three species of grebes started in mid-march in this Dayet, iii) the main nests of these grebes contained four or five eggs and the clutches size varied between 2 and 10 eggs according to the species.

Our work presented the abundance and distribution of the three sympatric grebes on the western side of Algeria. The main data on the grebe's species in Algeria was collected in the northeast part of the country (Senoussi, Nouidjem, Boulekhssaim, 2014; Abdellioui, Bensouilah, Houhamdi, 2015; Athamnia et al., 2015). However, no data on the phenology, abundances and breeding of black-necked grebe was reported in Algeria.

We noted that there was a significant difference in the number of grebes in the Dayet. This difference is probably explained by the water level fluctuation and food availability. Abdellioui, Bensouilah, Houhamdi (2015) reported that in Garaet 
Hadj-Tahar, the little and the great crested grebe had an annual variation according to water level throughout the year and the food resources in the wetlands.

The black-necked grebe has a highly dispersed characteristic in the western side of North Africa. Cherkaoui, Bouajaja, Elbanak, Lahrouz, Hanane (2013) reported an expending breeding behaviour of this species in the middle Atlas (Morocco) since 2009. Dayet El Ferd due to its vicinity to the middle Atlas was frequented from 2017 by breeding pairs of black-necked grebes. In northeastern Algeria, Black-necked grebe is confirmed as a rare wintering visitor (Metallaoui and Houhamdi, 2008).

The grebes selected its breeding area according to three parameters: size of the site, vegetation type and water level (Nudds, 1982). The breeding of grebes in the western part of Algeria started at the same period similarly as the grebes of the eastern part (Cheriet, Samraoui, Alfarhan, Samraoui, 2015; Athamnia et al., 2015). But, overall launching of grebes breeding in North Africa (mainly in Algeria) was earlier than in Central and Western Europe. Moss and Moss (1993), reported that in Britain and Ireland, grebes beginning breeding in April, peak in May, and the season extend to early September. In Slovenia, the great crested grebe started breeding from May to September (Vogrin, 1999).

The biometric characteristics of nests in the natural ecosystems reflected the social status of the individuals, age and experience (Lack, 1954). For example, the site selected by the grebes to build nests is highly correlated to breeding success (Athamnia et al., 2015). Martin (1993) reported that nests built up in high water depth reduced predator pressure, therefore, hatching success increased subsequently.

Compared to layings reported previously in the eastern part of Algeria, Athamnia et al. (2015) recorded a mean clutch size of $4.7 \pm 1.1$ eggs for little grebe and Rouibi, Zitouni, Tahar, Houhamdi (2013) recorded a mean clutch size of $2.81 \pm 1.30$ eggs for great crested grebe. These values display the large clutch size of grebes in western part of Algeria. This clutch size is influenced by environmental parameters. For example, Bara and Segura (2014) reported that the water level of the wetland and the rainfall changed the number of egg laid. In Dayet El Ferd, the level of water was influenced by the low level of rainfall (per. Obs.).

The failure rate of all these hatchings is associated with external or internal factors, resulting from the breeding area of the species. Ramdani, Kouidri, Ouakid, Houhamdi (2019) reported that, the hatching failures of eggs in birds are due to egg infertility, nest vandalism and nest predation (for grebes the main predators are snakes Natrix maura).

We strongly recommend a managing plan for this wetland in order to classifying them in Ramsar convention. We also recommend a specific studies on the grebes' distribution in the west part of North Africa (Algerian west coast and Moroccan Middle Atlas wetlands) and their relationship to food availability and breeding success. A genetic study of the grebes' population in Dayet El Ferd, also allows us to know the origins of grebes in this wetland. 


\section{ACKNOWLEDGMENTS}

The authors of this manuscript are especially grateful to the three reviewers for providing valuable suggestions and comments which greatly improved this paper.

\section{FINANCING}

This study is supported by the Algerian ministry of high education and scientific research, Laboratory Water Conservation Management Soil and Forest (University of Tlemcen) and Laboratory Biology, water and environment (University of Guelma).

\section{PARTICIPATION}

Houhamdi Moussa and Mostefai Noureddine developed and proposed this study, Moulay Meliani Khadidja and Bendahmane Ikram collected the data, Bara Mouslim and Atoussi Sadek performed the stat analysis and edited the manuscript. All authors reviewed this manuscript.

\section{CONFLICTS OF INTEREST}

There is no conflict of interest to report.

\section{LITERATURE CITED}

Abdellioui, S., Bensouilah, T., Houhamdi, M. (2015). Abundance and diurnal activity budget of sympatric Podicipedidae species at a Ramsar site in north-east Algeria. Zoology and Ecology, DOI:10.1080/21658005.2015.1074434.

Athamnia, M., Samraoui, F., Kelailia, B., Rouabah, A., Alfarhan, A., Samraoui, B. (2015). Nest-Site Selection and Reproductive Success of the Little Grebe Tachybaptus ruficollis in Northeast Algeria. Ardeola, 62 (1), 113-124.

Bara, M., Khelifa, R., Merzoug, S.E., Bouslama, Z., Houhamdi, M. (2014). Aspects of the breeding ecology of the Purple Swamphen Porphyrio porphyrio in the wetland complex of Guerbes-Sanhadja, north-east Algeria. Ostrich, journal of African ornithology, 85(2), 185-191.

Bara, M., Segura, L.N. (2019). Effect of Air Temperature and Water Depth on Bird Abundance: A Case Study of Rallidae and Anatidae in the Northeastern Algerian Garaet Hadj Tahar. Pakistan Journal of Zoology, 51(1), 211-217.

Benabadji, N., Bouazza, M. (2000). Few climatic modifications occurring in the southwest of Oran (occidental Algeria). Rev. En. Ren, 3, 117-125. 
Bendahmane, I., Mostefai N., Moulai-Melliani, K., Houhamdi, M. (2014). Statut phénologique de la famille des Anatidés dans la zone humide de Dayet El-Ferd, Tlemcen (Algérie). Bulletin de la Société Zoologique de France, 139 (1-4), 83-89.

Bendahmane, I., 2015. Breeding ecology of waterbirds of Dayet El Ferd (W. Tlemcen). PhD Thesis, University of Tlemcen.

Blondel, J. (1975). Analysis of waterbirds population: Ecological diagnosis element I. progressive frequency samples method. Terre \& Vie, 29, 533-589.

Cheriet, S., Samraoui, F., Alfarhan, A., Samraoui, B. (2015). Factors affecting nesting success in the Great-crested Grebe Podiceps cristatus at Lake Tonga, north-east Algeria. Ostrich: Journal of African Ornithology, DOI: 10.2989/00306525.201 5.1067932

Cherkaoui, I., Bouajaja, A., Elbanak, A., Lahrouz, S., Hanane, S. (2013). The Blacknecked Grebe (Podiceps nigricollis): an expanding species in the Middle Atlas wetlands, Morocco. Wetlands Ecol. Manage., DOI 10.1007/s11273-013-9321-7.

Fjeldså, J. (2004). Bird families of the world: the grebes. Oxford University Press, New York, New York, USA, New York.

Gilchrist, G., Mallory, M., Merkel, F. (2005). Can local ecological knowledge contribute to wildlife management? Case studies of migratory birds. Ecology and Society, 10 (1).

Lack, D. (1954). The natural regulation of animal numbers. Clarendon Press, Oxford.

Lumpkin, H.A., Pearson, S.M. (2013). Effects of exurban development and temperature on bird species in the southern Appalachian. Conservation Biology, 27, 1069-1078.

Martin, T.E. (1993). Nest predation and nest sites. BioScience, 43, 523-532.

Metallaoui, S., Houhamdi, M. (2008). Preliminary Data on the Aquatic Avifauna of Garaet Hadj Tahar (Skikda, Northeast Algeria). African Bird Club Bulletin, $15,71-76$.

Moss, D., Moss, G.M. (1993). Breeding biology of the Little Grebe Tachybaptusruficollis in Britain and Ireland. Bird Study, 40:2, 107-114.

Nudds, T. D. (1982). Ecological separation of grebes and coots: interference competition or microhabitat selection? Wilson Bulletin, 94, 505-514.

Ramdani, K., Kouidri, M., Ouakid, M. L., Houhamdi, M. (2019). Breeding biology of the chaffinch Fringilla coelebs africana in the El Kala National Park (North East Algeria). Arxius de Miscellània Zoològica, 17, 109-121.

Rouibi, A., Zitouni, A., Tahar, A., Houhamdi, M. (2013). Breeding ecology of the great crested grebe (Podiceps Cristatus) in Tonga Lake (Northeast Algeria). European Journal of Scientific Research, 100 (4), 534-541.

Senoussi, S., Nouidjem, Y., Boulekhssaim, M. (2014). The Wintering Behavior of the Great Crested Grebe (Podiceps Cristatus) and the Little Grebe (Tachybaptus Ruficollis) in the Lake Timerguanine (East of Algeria). World Journal of Environmental Biosciences, 7 (4), 19-28.

Summers, W. R., Mavor, A. R., Hogg, S., Harriman, R. (2011). Lake characteristics and their selection by breeding Slavonian Grebes Podiceps auritus in Scotland. Bird Study, 58, 349-356. 
Vogrin, M. (1999). Breeding ecology of the Great Crested GrebePodiceps cristatusin northeastern Slovenia. Ornis Hungarica, 8-9: 27-32. 